\title{
Long-term soil nitrogen and vegetation change on sandhill rangeland
}

\author{
W.A. BERG, J.A. BRADFORD, AND P.L. SIMS
}

Authors are soil scientist, plant physiologist, and range scientist, respectively, at the USDA-ARS Southern Plains Range Research Station, 2000 I8th Street, Woodward, Okla. 73801.

\section{Abstract}

The effect of livestock grazing on organic $\mathbf{C}$ and $\mathbf{N}$ in rangeland soils is not well defined. In this study on sandy rangeland in western Oklahoma, we sampled 8 pastures moderately grazed by cattle and 8 adjacent exclosures ungrazed by livestock for $\mathbf{5 0}$ years. The sagebrush was largely controlled by herbicide in the study areas. The $C$ and $N$ concentrations in the surface $5 \mathrm{~cm}$ of soil, total herbage production, and total $N$ uptake by vegetation were similar $(\boldsymbol{P}>0.05)$ in grazed and nongrazed areas. Carbon and $N$ concentrations in soils sampled to a constant mass to a depth of $5 \mathrm{~cm}$ or less were not $(P>0.05)$ different from concentrations determined on soil sampled to a constant depth of $5 \mathrm{~cm}$. When calculated on a content basis, grazing increased $(P<0.001)$ the bulk density $\left(1.35 \mathrm{~g} \mathrm{~cm}^{-3}\right)$ compared to nongrazed pastures $\left(1.19 \mathrm{~g} \mathrm{~cm}^{-3}\right)$ and had a significant $(P<0.01)$ effect on $\mathrm{C}$ and $\mathrm{N}$ in the surface $5 \mathrm{~cm}$ of soil. Litter and total $N$ in litter were greater $(P<0.01)$ on nongrazed areas. Little bluestem (Schizachyrium scoparium (Michx.) Nash) and sand bluestem (Andropogon hallii Hack.) produced more herbage and had greater frequency on nongrazed areas, whereas blue grama [Bouteloua gracilis (H.B.K.)Lag. ex Griffiths], sand dropseed [Sporobolus cryptandrus (Torr.)Gray], and western ragweed (Ambrosia psilostachya DC.) increased in frequency on grazed areas. Thus, 50 years of moderate grazing by cattle had no measurable effect on $\mathbf{C}$ and $\mathbf{N}$ concentrations in the surface $5 \mathrm{~cm}$ of the sandy soil or on total $\mathrm{N}$ uptake by plants as compared with nongrazed areas; however, significant differences occurred in species composition which may alter mechanisms of $\mathrm{C}$ and $\mathrm{N}$ balance.

Key Words: Southern Plains, soil sampling, organic carbon, litter, little bluestem, sand bluestem, western ragweed, grazing, exclosures

\footnotetext{
All programs and services of the U.S. Department of Agriculture are offered on a nondiscriminatory basis without regard to race, color, national origin, religion, sex, age, marital status or handicap.

Mention of a trade name or a specific proprietary product does not constitute a guarantee or warranty by authors or USDA-ARS nor does it imply the approval of these products to the exclusion of others.

The authors thank their predecessors for establishing the exclosures, the crew of 12 technicians and students who collected the vegetation data, Jerry McLaughlin for laboratory analyses, Tom Popham for statistical assistance, and Sherry Dewald for manuscript preparation.

Manuscript accepted 16 Nov. 1996.
}

Resúmen

El efecto del pastoreo del ganado en la el contenido de $\mathbf{C}$ y $\mathbf{N}$ el suelos de pastizales no esta bien definido. En este estudio se realizo en pastizales arenosos en el oeste de Oklahoma, donde muestreamos 8 pastizales moderadamente pastoreados por ganado vacuno y 8 pastizales adyacentes no-pastoreados por ganado vacuno durante 50 años. Artemisa filifolia (L.) fue controlado por herbicidas durante el estudio. Las concentraciones de $\mathrm{C}$ y $\mathrm{N}$ en la superficie del suelo $(5 \mathrm{~cm})$, producción de materia vegetal y cantidad total de $\mathrm{N}$ absorbido por la vegetacion fue similar $(\mathrm{P}>\mathbf{0 . 0 5})$ en patizales pastoreados y los no pastoreados. Concentrationes de $C$ y $\mathbf{N}$ en los suelos muestreados a una masa constante y a una profundidad de $5 \mathrm{~cm}$ no fue diferente $(P>0.05)$ a concentraciones determinadas en suelos muestreados a una profundidad constante de $5 \mathrm{~cm}$. Calculados en las bases de composicion, el pastoreo incremento $(P<0.001)$ la densidad del suelo $\left(1.35 \mathrm{~g} \mathrm{~cm}^{-3}\right) \mathrm{com}$ parando a los pastizales no pastoreados $\left(1.19 \mathrm{~g} \mathrm{~cm}^{-3}\right)$, ademas tubo un efecto significante $(\mathbf{P}<\mathbf{0 . 0 1})$ en el $\mathrm{C}$ y $\mathbf{N}$ en la superficie del suelo $(5 \mathrm{~cm})$. Rastrojos y $\mathbf{N}$ total en los rastrojos fueron superior $(P<0.01)$ en las áreas no pastoreadas. Schizachyrium scoparium Michx. (Nash) y Andropogon hallii (Hack.) producieron más vegetacion y tubieron mayor frecuencia en areas no pastoreadas, pero Bouteloua gracilis (H.B.K.) Lag. ex Griffiths, Sporobolus cryptandrus Torr. (Gray), y Ambrosia psilostachya (DC.) aumentaron en frecuencia en areas pastoreadas. Entonces, 50 años de pastoreo moderado por el ganado vacuno no tubo efectos considerables en la concentracion de $\mathbf{C}$ y $N$ en la superficie $(5 \mathrm{~cm})$ de suelos arenosos o en la absorcion total de $\mathbf{N}$ por las plantas comparadas con las areas no pastoreadas; Pero, diferencias significantes ocurrieron en la composiciûn de las especies, las cuales pueden alterar los mecanismos de balance de $\mathrm{C}$ y $\mathbf{N}$.

After water, $\mathbf{N}$ is usually the limiting factor in herbage production on rangeland. Grazing management that results in a net $\mathbf{N}$ loss to the system will eventually result in a loss in productivity. Organic C in soil is of interest from the standpoint of soil fertility, soil physical properties, and potential for $\mathrm{C}$ loss or sequestration as related to global climate change.

The major $\mathrm{N}$ inputs into Great Plains rangeland are atmospheric deposition and protein supplements fed to cattle; outputs include ammonia volatilized from plants and animal wastes, and livestock products sold (Woodmansee 1978, Lauenroth and Milchunas 1991). Redistribution of $\mathrm{N}$ within a pasture in livestock wastes 
results in $\mathrm{N}$ enrichment near watering sites, resting areas, and near fences; thereby diminishing $\mathrm{N}$ recycling onto the bulk of the pasture (Woodmansee 1978).

Annual $\mathrm{N}$ flux in rangeland is small in relation to total $\mathrm{N}$ in soil, vegetation, and litter. Therefore, long time periods are needed before measurable changes can be expected. A clear understanding of domestic livestock grazing effects on $\mathrm{C}$ and $\mathrm{N}$ in Great Plains soils has not emerged despite a number of studies on the Northern Plains (Bauer et al. 1987, Dormaar and Willms 1990, Dormaar et al. 1990, Dormaar et al. 1994, Frank et al. 1995, Johnston et al. 1971, Manley et al. 1995, Naeth et al. 1991, Smoliak et al. 1972). This may be because responses are often specific to site, grazing pressure, or season of grazing. Moreover, results among studies are often not directly comparable, since some studies report $\mathrm{C}$ and $\mathrm{N}$ concentrations and others $\mathrm{C}$ and $\mathrm{N}$ content. Also, some of the studies do not have true replication, making it uncertain if $\mathrm{C}$ and $\mathrm{N}$ differences reported are in response to grazing treatments or to soil variability.

Complications in measuring and comparing soil $\mathrm{C}$ and $\mathrm{N}$ under different grazing pressures arise in that soil bulk density usually increases because of compaction as grazing pressure increases. To illustrate 1 complication, consider sampling to a fixed depth (e.g. 5 or $10 \mathrm{~cm}$ ); then the grazing treatments with the highest bulk density (highest grazing pressure) will be sampled deeper into what was the pre-treatment soil profile. Since soil organic matter ( $\mathrm{C}$ and $\mathrm{N}$ ) usually decreases with soil depth, the soil sampled under the higher grazing pressure treatment (higher bulk density) may be biased to lower $\mathrm{C}$ and $\mathrm{N}$ concentrations (e.g. $\mathrm{g} \mathrm{N}$ $\mathrm{Kg}^{-1}$ soil to $10 \mathrm{~cm}$ depth).

The situation is further complicated when $\mathrm{C}$ and $\mathrm{N}$ content (e.g. $\mathrm{kg} \mathrm{N} \mathrm{ha}{ }^{-1}$ to $10 \mathrm{~cm}$ depth) is determined. This is because soil bulk density is used in the calculations and will give a bias toward higher $\mathrm{C}$ and $\mathrm{N}$ content in the treatment with the highest bulk density (Skene 1966, Henzell et al. 1967). To insure unbiased results, the sampling increment should be thicker for the less compacted soil if content comparisons are made. Henzell et al. (1967), Skene (1967), and R. Grossman (USDA-NRCS, Lincoln, NE, personal communication) suggest soil sampling approaches to correct the problem; however, a correction is complicated. Some studies have made a correction (Simpson et al. 1974), the problem has been mentioned in other studies (Manley et al. 1995), and overlooked in yet many others. Quantitative measures of species change and $\mathrm{N}$ and $\mathrm{C}$ dynamics in soils under long-term grazing regimes should provide some insight into how different species impact nutrient cycling in rangeland ecosystems (Hobbie 1992, Tilman and Wedin 1991).

The primary objective of this study was to determine $\mathrm{N}$ in soil, vegetation, and litter in grazed Southern Great Plains sandhills rangeland as compared to adjacent areas where cattle grazing was excluded for 50 years. The sand sagebrush has been largely controlled with 2,4-D herbicide in the study areas. Also reported are data on soil $\mathrm{C}$ and $\mathrm{N}$ concentrations from sampling on a constant mass basis as compared to sampling to a given depth and reporting $\mathrm{C}$ and $\mathrm{N}$ concentrations or contents.

\section{Materials and Methods}

\section{The Setting}

The study was conducted on the USDA Southern Plains Experimental Range 2-km north of Fort Supply $\left(99^{\circ} 23^{\prime} \mathrm{W}, 36^{\circ}\right.$ $27^{\prime} \mathrm{N}$, Elevation 610-640 m) in western Oklahoma. The Experimental Range includes 1,746 ha of native sandhill rangeland (Berg 1994) which in 1936 was "observed to be in extremely poor condition as a result of severe drought, intense heat and close grazing."

The native vegetation is within the sand sagebrush (Artemisia filifolia Torr.)-bluestem prairie type of Kuchler (1964). The topography is that of rolling sandhills with no well-defined drainage patterns. Pratt soils (sandy, mixed thermic Psammentic Haplustalfs) are on lower slopes and more level areas, and Tivoli soils (mixed, thermic Typic Ustipsamments) are on upper slopes. The 50-year mean annual precipitation is $575 \mathrm{~mm}$. The area had major droughts in the 1930's and 1950's, above average precipitation 1985 to 1989 (ave. $690 \mathrm{~mm} \mathrm{yr}^{-1}$ ), and $435 \mathrm{~mm}$ in 1990,409 $\mathrm{mm}$ in 1991, $386 \mathrm{~mm}$ in 1992, and $460 \mathrm{~mm}$ in 1993.

In 1941, experimental pastures (20 to $80 \mathrm{ha}$ ) and associated livestock exclosures ( 0.4 to $4 \mathrm{ha}$ ) were fenced ( 4 wires) prior to starting rotational grazing (Mcllvain and Savage 1951) and cattle stocking rate studies (Shoop and Mcllvain 1971). Sand sagebrush has been nearly eliminated on some portions of the experimental pastures and on portions of the associated exclosures by herbicide spraying that began in 1946 (Mcllvain and Savage 1949).

Sixteen pastures and associated exclosures were evaluated as possible sites for this study. Eight sites were selected that were: 1) on Pratt loamy sand soils, 2) devoid or nearly devoid of sand sagebrush, 3) on uniform topography within a sampling area of 20 by $100 \mathrm{~m}$ within the exclosure and a paired area in the adjacent pasture. Adjacent paired sampling areas were parallel and separated by a $10-\mathrm{m}$ wide strip on the pasture side of the exclosure fence to avoid sampling where cattle concentrations may have occurred as a result of grazing and traveling.

The 8 pastures associated with the exclosures were grazed 'moderately' with 0.29 yearling steer $\mathrm{ha}^{-1} \mathrm{yr}^{-1}$ or 0.14 cow-calf pairs ha$\mathrm{yr}^{-1}$ since 1961. Moderate stocking under year-long grazing was defined as the level of grazing that left approximately $1 / 3$ of the average production of forage at the end of the grazing period, usually about 20 April (Shoop and McIlvain 1971). From 1942 to 1961,6 of the pastures were grazed under moderate stocking and 2 pastures under heavy stocking $\left(0.38\right.$ steers $\left.\mathrm{ha}^{-1} \mathrm{yr}^{-1}\right)$. Cattle were supplemented in winter with about $0.9 \mathrm{~kg}$ cottonseed cake $(41 \%$ crude protein) day ${ }^{-1}$ head $^{-1}$. Residue within 1 exclosure was accidently burned in 1943, 1 exclosure was intentionally burned in 1951 , and 1 exclosure accidently burned in 1959. Some soil disturbance by pocket gophers (Geomys bursarius Shaw) and kangaroo rats (Dipodomys ordii Woodhouse) was obvious both within and outside the exclosures.

\section{Soil Sampling and Analysis}

Soil samples were taken when the soil was moist so that intact cores could be extracted. Sampling was in spaces between plant bases and random except that samples were not taken where rodent disturbance was obvious. Litter was hand brushed aside to bare the sampling area. Ten cores were taken in each pasture and 10 in each adjacent exclosure during June 1992.

Preweighed soil sample rings (stainless steel cylinders 50- $\mathrm{mm}$ diameter, 50-mm tall; Eijkelkamp Co.; Giesebeek, The Netherlands) were pushed into the soil until the top was flush

'D.A. Savage, 1941 file report "Preliminary grazing treatments on the Southern Plains Experimental Range", Southern Plains Range Research Station, Woodward, Okja. 
with the soil surface. The samples, still in the rings, were removed and dried at $57^{\circ} \mathrm{C}$ and bulk density calculated.

The soil cores from within pastures and exclosures were then randomly divided into 2 groups. On 1 group the following procedure was used so soil $\mathrm{N}$ and $\mathrm{C}$ concentrations could be determined on equal sampled soil masses using the soil surface as the plane of reference. Within each paired set of 10 core samples, 5 from a given pasture and 5 from the associated exclosure, the soil weight of each sample was adjusted to the weight of the lightest sample. This was done by uniformly shaving and discarding soil off the bottom of each of the other samples (still in the sample rings) until the soil sample weights were uniform among the 10 samples. On the other group of samples, the entire soil volume within the sampling rings was processed and analyzed.

Soil samples were crushed and sieved through a 2-mm screen. Roots visible in the sieved samples were removed. Total $\mathrm{N}$ was determined by a micro-kjeldahl procedure (Bremner and Breitenbeck 1983) and organic $\mathrm{C}$ determined by the modified Mebius method (Nelson and Sonmers 1982). The soils were noncalcareous and had a $\mathrm{pH}$ (vol:vol, soil:distilled water) range of 5.5 to 6.8 .

\section{Vegetation and Litter Sampling and Analyses}

Pasture sampling areas were fenced to exclude livestock in March 1993. Vegetation and litter were sampled over the period of 26 to 30 July 1993 . Within each 20 by $100-\mathrm{m}$ sampling area the location of 20 sampling stations was randomly assigned. If a sample station fell within the canopy of a sand sagebrush plant, this station was voided and another station used.

Frequency of species rooted within a $0.1-\mathrm{m}^{2}$ quadrat was recorded at each sampling station and at 4 additional quadrat placements each $1.5-\mathrm{m}$ in a cardinal direction from the original station. This gave frequency on $1000.1-\mathrm{m}^{2}$ quadrats per pasture or exclosure. Only species with a frequency averaging $5 \%$ or more in either the pastures or exclosures are reported.

Herbage was clipped by species or classes of species from plants rooted within a 0.30 by $1.66-\mathrm{m}\left(0.5 \mathrm{~m}^{2}\right)$ quadrat at each of the 20 sampling stations within each sample area. Clipping was near the soil level. The clippings were dried at $57^{\circ} \mathrm{C}$ and weighed. All clippings within a species or class of species within each sample area were composited, subsampled, and ground to pass a 1-mm screen. Total $\mathrm{N}$ concentration was determined by the procedures of Bremner and Breitenbeck (1983).

Litter, which included standing dead material (pre 1993 growing season), was collected within each $0.5 \mathrm{~m}^{2}$ quadrat after herbage was clipped, dried at $57^{\circ} \mathrm{C}$, ground to pass a $1.0-\mathrm{mm}$ screen, and total $\mathrm{N}$ concentration was determined (Bremner and Breitenbeck 1983). Litter was ashed at $600^{\circ} \mathrm{C}$ to correct for soil contamination and is reported on an organic matter basis.

Soil data, vegetation and litter weights, and $\mathrm{N}$ levels were analyzed by analysis of variance. The model was a randomized complete block design. The 8 sampling sites were blocks. Species frequency was analyzed using the Chi square test.

\section{Results and Discussion}

\section{Soils}

Grazing had no significant $(P>0.05$ ) effect on $C$ and $N$ concentrations (Table 1). Carbon and $\mathrm{N}$ concentrations determined in soils sampled to a constant mass to a depth of $5 \mathrm{~cm}$ or less were
Table 1. Total $N$ and organic $C$ in soils under grazed pastures and nongrazed exclosures in a Southern Plains mixed grass prairie.

\begin{tabular}{|c|c|c|c|}
\hline Measurement & Grazed & Nongrazed & $\begin{array}{l}\text { Level of } \\
\text { significance }\end{array}$ \\
\hline \multicolumn{4}{|c|}{$\begin{array}{l}\text { Concentration when sampled to a constant mass to a depth of } 5 \mathrm{~cm} \text { or } \\
\text { less: }\end{array}$} \\
\hline Total $\mathrm{N}, \mathrm{g} \mathrm{kg}^{1}$ & $1.16 \pm 0.08$ & $1.06 \pm 0.07$ & NS \\
\hline Organic C, $\mathrm{g} \mathrm{kg}^{-1}$ & $10.44 \pm 0.90$ & $9.51 \pm 0.77$ & NS \\
\hline \multicolumn{4}{|c|}{ Concentration when sampled to $5 \mathrm{~cm}$ : } \\
\hline Total $\mathrm{N}, \mathrm{g} \mathrm{kg}^{-1}$ & $1.11 \pm 0.07$ & $1.04 \pm 0.10$ & NS \\
\hline Organic $\mathrm{C}, \mathrm{g} \mathrm{kg}^{-1}$ & $10.38 \pm 0.82$ & $8.89 \pm 1.24$ & NS \\
\hline \multicolumn{4}{|c|}{ Content when sampled to $5 \mathrm{~cm}$ : } \\
\hline Total $\mathrm{N}, \mathrm{g} \mathrm{m}^{-2}$ & $74 \pm 4$ & $61 \pm 5$ & ** \\
\hline Organic $\mathrm{C}, \mathrm{g} \mathrm{m}^{-2}$ & $694 \pm 47$ & $520 \pm 62$ & ** \\
\hline
\end{tabular}

not $(P>0.05)$ different from concentrations determined on soil sampled to a constant depth of $5 \mathrm{~cm}$. Thus in this study, sampling to a constant mass gave nearly the same results and was considerably more laborious than sampling to a constant depth. When calculated on a content basis (Table 1 ), grazing had a significant $(P<0.01)$ effect on $\mathrm{C}$ and $\mathrm{N}$ in the surface $5 \mathrm{~cm}$ of soil. The higher $(\mathrm{P}<0.001)$ bulk density measured in the grazed pastures $(1.35 \mathrm{~g} \mathrm{~cm}-3)$ than in the exclosures $\left(1.19 \mathrm{~g} \mathrm{~cm}^{-3}\right)$ used in the content calculations led to this difference. We believe that the comparison of these $\mathrm{C}$ and $\mathrm{N}$ contents based on a constant sampling depth are invalid for the reasons given by Skene (1966) and Henzell et al. (1967).

Thus, we suggest that the soil concentrations of $\mathrm{C}$ and $\mathrm{N}$ best reflect the effect of cattle grazing as compared to 50 years of exclusion on the study areas. Our data can be criticized for the shallow sampling depth; however, grazing effects in improved pastures are usually most pronounced in the surface $5 \mathrm{~cm}$ (Whitehead 1995). In areas adjacent to this exclosure study significant soil $\mathrm{C}$ and $\mathrm{N}$ differences between nonfertilized and 20year $\mathrm{N}$-fertilized pastures were found only in the surface $5 \mathrm{~cm}$ (Berg 1988).

In future rangeland soil studies, increased attention should be given to sampling depths (Skene 1966, Henzell et al. 1967), reporting $\mathrm{C}$ and $\mathrm{N}$ concentrations (Reganold and Palmer 1995) and/or contents (Tiessen et al. 1982, Manley et al. 1995), and valid field replication (Hurlbert 1984, Wester 1992). Consistent sampling of adjacent pastures showing vegetation contrasts induced by moderate as compared to heavy grazing over many locations may be a fruitful approach to determine grazing effects on soil $\mathrm{C}$ and $\mathrm{N}$ in the Great Plains. Rauzi et al. (1968) used such an approach to characterize infiltration rates.

\section{Vegetation}

Total herbage production and total herbage $\mathrm{N}$ uptake (Table 2) were not significantly different $(P>0.05)$ between grazed pastures and nongrazed exclosures. Among species there were many significant differences between grazed pastures and nongrazed exclosures in herbage production (Table 2), $\mathrm{N}$ uptake (Table 2) and frequency (Table 3). The removal of sand sagebrush with herbicide altered the vegetation structure and may have impacted long-term $\mathrm{C}$ and $\mathrm{N}$ dynamics that were not measured in this study.

Total grass production averaging $1,280 \mathrm{~kg} \mathrm{ha}^{-1}$ in the grazed pastures in this study (Table 2) is comparable to forage production averaging $1,200 \mathrm{~kg} \mathrm{ha}^{-1} \mathrm{yr}^{-1}$ measured in some of these and 
Table 2. Herbage production and $\mathrm{N}$ uptake by important species and classes of species in grazed pastures and nongrazed exclosures in a Southern Plains mixed grass prairie.

\begin{tabular}{|c|c|c|c|c|c|c|}
\hline Species & \multicolumn{3}{|c|}{ Herbage } & \multicolumn{3}{|c|}{ N uptake } \\
\hline Blue grama & $147 \pm 20$ & $4 \pm 2$ & ** & $1.40 \pm .19$ & $0.09 \pm .04$ & ** \\
\hline Sand bluestem & $302 \pm 35$ & $494 \pm 65$ & $* *$ & $2.22 \pm .25$ & $3.66 \pm .44$ & ** \\
\hline Sand dropseed & $53 \pm 7$ & $6 \pm 2$ & ** & $0.50 \pm .07$ & $0.07 \pm .03$ & ** \\
\hline Texas bluegrass & $134 \pm 52$ & $115 \pm 18$ & $* *$ & $1.70 \pm .66$ & $1.51 \pm .23$ & $*$ \\
\hline Other grasses & $319 \pm 37$ & $302 \pm 26$ & NS & $2.66 \pm .29$ & $2.30 \pm .20$ & NS \\
\hline Perennial forbs & $484 \pm 33$ & $138 \pm 13$ & ** & $1.21 \pm .02$ & $1.61 \pm .03$ & ** \\
\hline Total forbs & $772 \pm 44$ & $325 \pm 29$ & $* *$ & $4.25 \pm .36$ & $4.01 \pm .36$ & ** \\
\hline Total herbage & $2052 \pm 83$ & $2139 \pm 106$ & NS & $15.04 \pm .94$ & $17.83 \pm .86$ & NS \\
\hline
\end{tabular}

${ }^{*}=\mathrm{P}>\mathrm{F} .05,{ }^{* *}=\mathrm{P}>\mathrm{F} .01$

similar pastures over the period 1950-1960 (Shoop and McIlvain 1971). These production data and total precipitation of $438 \mathrm{~mm}$ for the October 1992 through July 1993 period (54 year Oct. through July mean $=452 \mathrm{~mm}$ ) indicate that vegetation sampling in July 1993 was done after near-normal precipitation conditions.

Comparing species, blue grama and sand dropseed produced more herbage, accounted for greater $\mathrm{N}$ uptake (Table 2), and had greater frequency (Table 3 ) in grazed areas; little bluestem and sand bluestem produced more herbage, accounted for greater $\mathrm{N}$ uptake, and had greater frequency in nongrazed areas. Nitrogen uptake by little bluestem and sand bluestem was $55 \%$ of total $\mathrm{N}$ uptake by plants in the nongrazed areas and $24 \%$ of total $\mathrm{N}$ uptake in the grazed areas (Table 2). Although Texas bluegrass (Poa arachnifera Torr.) had significantly higher $(\mathrm{P}>.001)$ frequency in the nongrazed area, its herbage production $(\mathrm{P}>.01)$ and $N$ uptake $(P>.05)$ was significantly higher in the grazed area.

Perennial forb production was 3 -fold greater in the grazed than in the nongrazed areas (Table 2). Nearly a third of total $\mathrm{N}$ uptake

Table 3. Frequency of species within $0.1 \mathrm{~m}^{-2}$ quadrats in grazed pastures and nongrazed exclosures in a Southern Plains mixed grass prairie.

\begin{tabular}{lrrl}
\hline \hline Species & Grazed & Nongrazed & $\begin{array}{l}\text { Chi square } \\
\text { Probability }\end{array}$ \\
\hline Perennial grasses: & 35 & 3 & 0.001 \\
Blue grama & 24 & 46 & 0.001 \\
Littlc bluestem & 37 & 43 & 0.030 \\
Sand bluestem & 11 & 1 & 0.001 \\
Sand dropseed & 7 & 1 & 0.001 \\
Sand paspalum & 5 & 3 & 0.110 \\
Switchgrass & 29 & 42 & 0.001 \\
Texas bluegrass & & & \\
Annual grasses: & 17 & 8 & 0.001 \\
Annual bromes & 7 & 1 & 0.001 \\
Sandbur & & & \\
Perennial forbs: & 14 & 8 & 0.080 \\
Heath aster & 1 & 7 & 0.001 \\
Silverleaf nightshade & 5 & 19 & 0.001 \\
Spiderwort & 75 & 35 & 0.001 \\
Western ragweed & & & \\
Annual forbs: & 36 & 17 & 0.001 \\
Camphor weed & 0 & 5 & 0.001 \\
Sunflower & 16 & 4 & 0.001 \\
Wooly plantain & & & \\
\hline
\end{tabular}

by plants in grazed areas was by annual and perennial forbs (Table 2). This compares to about $20 \%$ of total N uptake in nongrazed areas by forbs. Much of the perennial forb production and $\mathrm{N}$ uptake was by western ragweed which had the highest frequency of any species in the pastures (Table 3). Heath aster (Aster ericoides L.), Camphor weed (Heterotheca latifolia Buckl.) and wooly plantain (Plantago patagonica Jacq.) were important forbs, particularly in the grazed mixed grass prairie. Silverleaf nightshade (Solanum elaeagnifolium Cav.), Spiderwort (Tradescantia occidentalis (Britt) Smyth), and sand sunflower (Helianthus petiolaris Nutt.) were more prominent in the nongrazed exclosures (Table 3). Bromes (Bromus spp.) and sandbur (Cenchrus incertus M.A. Curtis) were important annual grasses, particularly in the grazed areas.

\section{Litter}

Nongrazed areas contained more than twice as much litter and standing dead tissue as the grazed areas (Table 4). Total $\mathrm{N}$ in litter and standing dead tissue in the nongrazed areas $\left(27 \mathrm{~kg} \mathrm{~N} \mathrm{ha}^{-1}\right)$ was more than 3 -fold more than in the grazed areas (Table 4). This quantity of $N$, apparently accumulated over 50 years, is about equal to annual $N$ uptake in herbage (Table 2) and is small in relation to total soil $\mathrm{N}$.

Table 4. The amount of litter and litter $N\left(\mathrm{~kg} \mathrm{ha}^{-1}\right)$ in grazed pastures and nongrazed exclosures in a Southern Plains mixed-grass prairie.

\begin{tabular}{lccc}
\hline \hline Measurement & Grazed & Nongrazed & $\begin{array}{c}\text { Level of } \\
\text { significance }\end{array}$ \\
\hline Litter & $\left(\mathrm{kg} \mathrm{ha}^{-1}\right)$ & $\left(\mathrm{kg} \mathrm{ha}^{-1}\right)$ & \\
N content & $1158 \pm 88$ & $3210 \pm 175$ & $* *$ \\
$T_{*}=\mathrm{P}>$ F $.05, * *=\mathrm{P}>$ F .01 & $8 \pm 1$ & $27 \pm 2$ & $* *$
\end{tabular}

\section{Conclusions}

Fifty years of livestock exclusion had no measurable effect on $\mathrm{C}$ and $\mathrm{N}$ concentration in the surface $5-\mathrm{cm}$ of soil, total herbage production, or total plant uptake of $\mathrm{N}$, as compared to adjacent moderately grazed rangeland. Litter and total $\mathbf{N}$ in litter were greater under nongrazed conditions. Since similar measurements 
were not made at the time the exclosures were constructed, conclusions on $\mathrm{C}$ and $\mathrm{N}$ trends in these grazed and nongrazed systems are not possible. However, the data indicates that moderate grazing by cattle on this mixed-grass prairie rangeland had little measurable effect on the $\mathrm{N}$ status as compared to nongrazed conditions.

Substantial differences in frequency and herbage production among plant species were present when comparing grazed and nongrazed conditions. Little bluestem was a major producer in nongrazed areas; whereas western ragweed, blue grama, and sand dropseed were more common on grazed areas. The prominence of western ragweed on the grazed areas indicates that this species should be of major interest in future grazing management studies in the region.

These data indicate that plant species are both a cause and an effect of patterns of nutrient cycling as suggested by Hobbie (1992). Species responses to grazing in this study appeared related to herbivore selectivity, grazing tolerance, and above-ground net primary production of the various species of vegetation as hypothesized by Milchanus and Lauenroth (1993). Selective foraging by herbivores, which serve as functional switches in the food web and nutrient cycles (Pastor and Naiman 1992), facilitated shifts in the plant community structure of this mixed-grass prairie ecosystem.

In our study, sand and little bluestem together accounted for 30 and 55 percent of the $\mathrm{N}$ uptake in grazed and nongrazed mixed grass prairie, respectively. Tilman and Wedin (1991) found that Andropogon and Schizachyrium species were at an advantage over other species in these less fertile grasslands because of their higher proportion of root biomass, relatively low root and shoot $\mathrm{N}$ concentrations, and slow growth rates. Forbs like western ragweed can significantly impact nutrient cycling when conditions favor their growth, i.e., in normal to wet years following dry summers when the density of warm season perennial grasses have declined. The presence of the cool-season perennial Texas bluegrass and annual bromes may also extend the nutrient cycling and $\mathrm{C}$ sequestration during the annual cycles.

\section{Literature Cited}

Bauer, A., C. V. Cole, and A. L. Black. 1987. Soil property comparisons in virgin grasslands between grazed and nongrazed management system. Soil Sci. Soc. Amer. J. 51:176-182.

Berg, W. A. 1988. Soil nitrogen accumulation in fertilized pastures of the Southern Plains. J. Range Manage. 41:22-25.

Berg, W. A. 1994. Sand sagebrush-mixed prairie. p. 99 . In: T. N. Shiftlet (ed.), Rangeland cover types of the United States. Soc. Range Management. Denver, Colo.

Bremner, J. M. and G. A. Breitenbeck. 1983. A simple method for determination of ammonium in semimicro-kjeldahl analysis of soils and plant materials using a block digester. Commun. Soil Sci. Plant Anal. 14:905-913.

Dormaar, J. F. and W. D. Willms. 1990. Effect of grazing and cultivation on some chemical properties of soils in the mixed prairie. J. Range Manage. 43:456-460.

Dormaar, J. F., S. Smoliak, and W. D. Willms. 1990. Distribution of nitrogen fractions in grazed and ungrazed grassland Ah horizons. J. Range Manage. 43:6-9.

Dormaar, J. F., B. W. Adams, and W. D. Willms. 1994. Effect of grazing and abandoned cultivation on a Stipa-Bouteloua community. J. Range Manage. 47:28-32.
Frank, A. B., D. L. Tanaka, L. Hofmann, and R. F. Follett. 1995. Soil carbon and nitrogen of Northem Great Plains grasslands as influenced by long-term grazing. J. Range Manage. 48:470-474.

Henzell, E. F., I. F. Fergus, and A. E. Martin. 1967. Accretion studies of soil organic matter. J. Australian Inst. Agr. Sci. 33:35-37.

Hobbie, S. A. 1992. Effects of plant species on nutrient cycling. TREE 7:336-339.

Hurlbert, S. H. 1984. Pseudoreplication and the design of ecological field experiments. Ecol. Monogr. 54:187-211.

Johnston, A., J. F. Dormaar, and S. Smoliak. 1971. Long-term grazing effects on fescue grassland soils. J. Range Manage. 24:185-188.

Kuchler, A. W. 1964. Potential natural vegetation of the conterminous United States. Amer. Geographical Soc. Special Pub. 36.

Lauenroth, W. K. and D. G. Milchunas. 1991. Short-grass steppe. p. 183-218. In R.T. Coupland (ed.) Ecosystems of the World 8a, Natur. Grassl. Elsevier, Amsterdam.

Manley, J. T., G. E. Schuman, J. D. Reeder, and R. H. Hart. 1995. Rangeland soil carbon and nitrogen responses to grazing. J. Soil Water Conserv. 50:294-298.

Mcllvain, E. H. and D. A. Savage. 1949. Spraying 2,4-D by airplane on sand sagebrush and other plants of the Southern Great Plains. J. Range Manage. 2:43-52.

McIlvain. E. H. and D. A. Savage. 1951. Eight year comparisons of continuous and rotational grazing on the Southern Plains Experimental Range. J. Range Manage. 4:42-47.

Milchanus, D. G., and W. K. Lauenroth. 1993. Quantitative effects of grazing on vegetation and soils over a global range of environments. Ecol. Monogr. 63:327-366.

Naeth, M. A., A. W. Bailey, D. J. Pluth, D. S. Chanasyk, and R. T. Hardin. 1991. Grazing impacts on litter and soil organic matter in mixed prairie and fescue grassland ecosystems of Alberta. J. Range Manage. 44:7-12.

Nelson, D. W. and L. E. Sommers. 1982. Total carbon, organic carbon and organic matter. p. 539-579. In A. L. Page (ed.) Methods of Soil Analysis, Part 2, second edition. ASA. Madison, Wisc.

Pastor, J. and R. J. Naiman. 1992. Selective foraging and ecosystem processes in boreal forests. The Amer. Natur. 139:690-705.

Rauzi, F., C. L. Fly, and E. J. Dyksterhuis. 1968. Water intake of Midcontinental rangelands as influenced by soil and plant cover. USDA Tech. Bull. 1390. 58 p. U. S. Government Printing Office. Washington, D.C

Keganold, J. P. and A. S. Palmer. 1995. Significance of gravimetric versus volumetric measurements of soil quality and biodynamic, conventional, and continuous grass management. J. Soil Water Cons. 50:298-305.

Shoop, M. C. and E. H. McIlvain. 1971. Why some cattlemen overgraze- and some don't. J. Range Manage. 24:252-257.

Simpson, J. R., S. M. Bromfield, and O. L. Jones. 1974. Effects of management on soil fertility under pasture. 3. Changes in total soil nitrogen, carbon, phosphorus and exchangeable cations. Aust. J. Exp. Agr. Anim. Husb. 14:487-494.

Skene, J. K. M. 1966. Errors in accretion studies of soil organic matter. J. Australian Inst. Agr. Sci. 32:208-209.

Skene, J. K. M. 1967. Letter to editor. J. Australian Inst. Agr. Sci. 33:37.

Smoliak, S., J. F. Dormaar, and A. Johnston. 1972. Long-term grazing effects on Stipa-Bouteloua prairie soils. J. Range Manage. 25:246-250.

Tiessen, H., J. W. B. Stewart, and J. R. Bettany. 1982. Cultivation effects on the amounts of carbon, nitrogen, and phosphorus in grassland soils. Agron. J. 74:831-835.

Tilman, D., and D. Wedin. 1991. Plant traits and resource reduction for five grasses growing on a nitrogen gradient. Ecol. 72:685-700.

Wester, D. B. 1992. Viewpoint: Replication, randomization, and statistics in range research. J. Range Manage. 45:285-290.

Whitehead, D. C. 1995. Grassland nitrogen. CAB International, Wallingford, UK.

Woodmansee, R. G. 1978. Additions and losses of nitrogen in grassland ecosystems. BioSci. 28:448-453. 